\title{
Re-examination of the standards for transit oriented development influence zones in India
}

\author{
Sangeetha Ann \\ Nagoya University \\ sangeetha.ann@gmail.com \\ Toshiyuki Yamamoto \\ Nagoya University \\ yamamoto@civil.nagoya-u.ac.jp
}

\author{
Meilan Jiang \\ Nagoya University \\ jiangml@trans.civil.nagoya-u.ac.jp
}

\begin{abstract}
Transit oriented development (TOD) is a land-use and transport integrated urban planning strategy that is highly acclaimed for promoting sustainable city development. This review aims to identify the problems regarding adoption of TOD standards or guidelines formulated by developed countries in developing countries, such as India, and the necessity of conducting adaptability studies on TOD influence areas. The existing studies show that the size of the influence area varies among different cities and travel modes. Accordingly, no single size influence zone is suitable for all cases. This review highlights the necessity of carefully considering the spatial extent of influence areas and modes other than walking as access or egress modes in the Indian context. Moreover, this review aims to provide insight on how to plan TOD in the context of developing countries, because the mobility patterns in these countries differ considerably from those in the developed world.
\end{abstract}

\section{Article history:}

Received: February 14, 2019

Received in revised form:

July 29, 2019

Accepted: August 5, 2019

Available online: September 20,

2019

\section{$1 \quad$ Introduction}

Transit oriented development (TOD) is a concept focusing on station area development linking transit, land use and community living and was popularized by Peter Calthorpe in his book "The New American Metropolis" (Calthorpe, 1993; Carlton, 2007). TOD as a planning strategy was derived in North America where large cities have experienced low-density sprawl, which has worsened traffic congestion and degraded the quality of the environment in the 1990's (Sung, 2011). Cities in Europe and Asia have historically been transit oriented with mixed land use, pre dominance of pedestrians and cyclists, and transit services (Renne, 2009; Thomas, et al., 2018).

The TOD integrates land use and transport for the enhancement of urban communities with the primary goal of increasing transit use and other means of sustainable transport, such as walking and cycling. Moreover, various studies have been performed to understand the TOD and its elements and to specify the standards for its planning. The TOD has multiple definitions, and various cities in the

Copyright 2019 Sangeetha Ann, Meilan Jiang, \& Toshiyuki Yamamoto

http://dx.doi.org/10.5198/jtlu.2019.1534

ISSN: $1938-7849$ | Licensed under the Creative Commons Attribution - Noncommercial License 4.0

The Journal of Transport and Land Use is the official journal of the World Society for Transport and Land Use (WSTLUR) and is published and sponsored by the University of Minnesota Center for Transportation Studies. 
developed world have adopted guidelines and standards for its planning and implementation. The influence area is a major element in the TOD; typically, a half-mile radius (approximately $800 \mathrm{~m}$ ) is adopted as the basic dimension for this area in relation to the TOD planning in developed countries. However there is lack of consensus among researchers on whether this is a correct practice. Furthermore, in recent Nies, such as India, have started adopting the TOD as part of their ch planning strategies. The government of India published the National Transit Oriented Development Policy and corresponding guidelines to assist their cities in the adoption of TOD. However, it should be noted that these guidelines are substantially based on strategies devised by developed countries; thus, it is necessary to examine their suitability in the context of Indian cities. This study discusses the extent of the TOD influence area and the problems related to it. The objective of the paper is to establish the need for research regarding TOD influence areas in Indian cities and does not focus a general literature review. There is a dearth of data and research regarding mobility research in India and the existing studies show that the influence areas can be extended to a larger area than specified in the policy. The methodology used for this paper is given in Fig. 1.

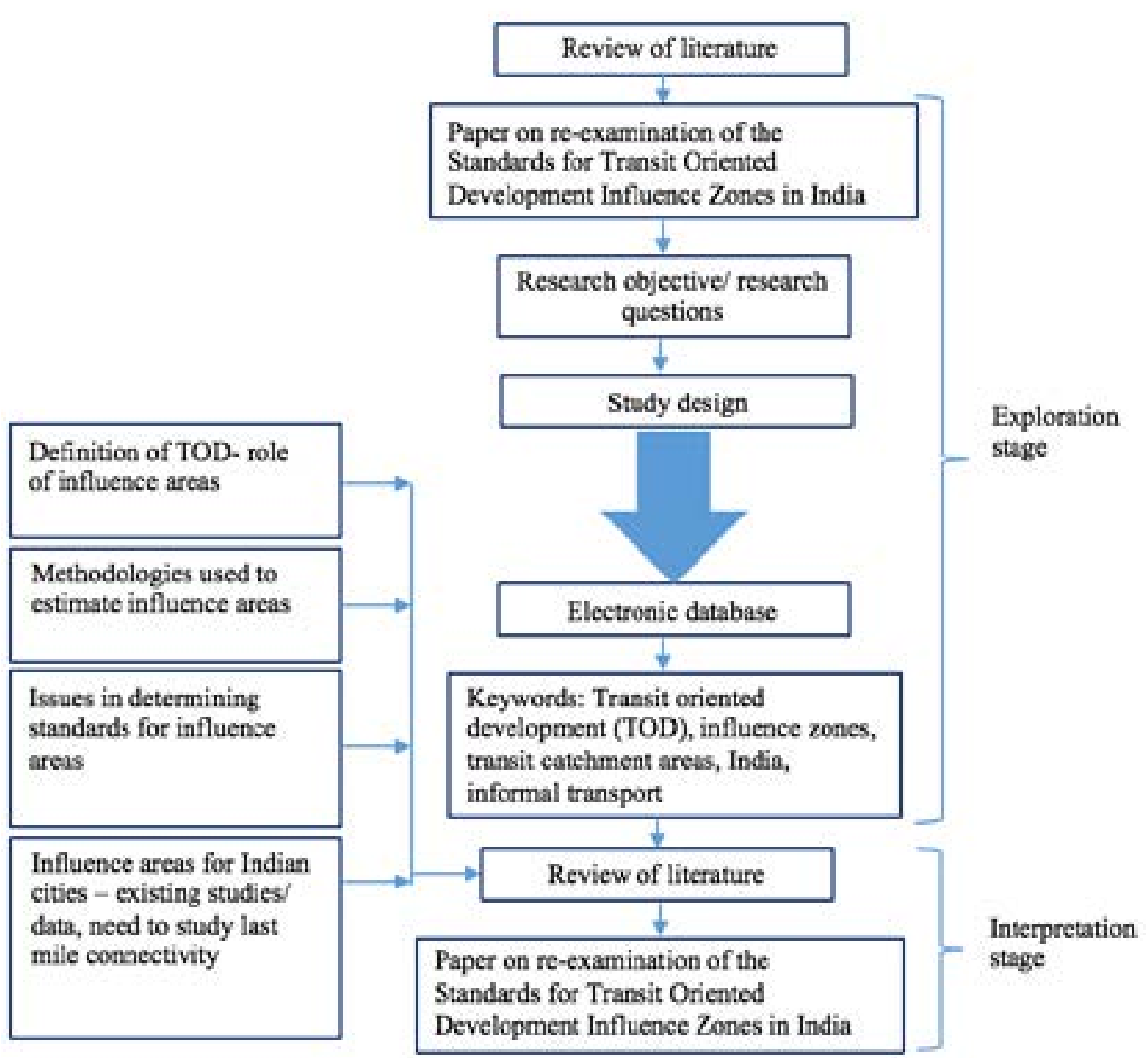

Figure 1. Study methodology
This paper is structured into six sections. The background is presented in Section 1. The definition of the TOD is discussed in Section 2. Section 3 explains the influence areas of TODs and a general view of how these influence zones are determined. Section 4 discusses the problems in determining the standards for influence areas. Section 5 presents the TOD influence zones in Indian cities. The conclusion and future direction of the study are provided in Section 6 .

\section{Definitions of TOD}

The TOD has no universal definition. Some of the definitions found in literature are given below: 1. "A mixed-use community within an average 2,000-feet (or 10-minute) walking distance of a transit stop and core commercial area. TOD mixes residential, retail, office, open space, and public uses in a walkable environment, making it convenient for residents and employees to travel by transit, bicycle, foot, or car" (Calthorpe, 1993)

2. "Development within a specified geographical area around a transit station with a variety of and uses and a multiplicity of landowners" (Salvensen, 1996)

3. "The practice of developing or intensifying residential land use near rail stations" (Boarnet \& Crane, 1998)

4. "A mixed-use community that encourages people to live near transit services and to decrease their dependence on driving" (Still, 2002)

5. "Mix of uses, at various densities, within a 1/2-mile radius around each stop" (Dittamar \& Ohland, 2004)

6. "An approach to expansion that aims to encourage the development of mixed use and compact, increasing the number of passengers of public transport and creating more livable communities" (Arrington \& Cervero, 2008)

7. "Concentrated mix of moderately dense and pedestrian friendly development around transit stations to promote transit riding, increased walk and cycle travel and other alternatives to use of private cars" (Cervero, 2009)

8. "A planning technique that aims to reduce automobile use and promote the use of public transit and human-powered transportation modes through high density, mixed-use, and environmentally friendly development within areas of walking distance from transit centers" (Sung, 2011)

One of the main learnings gained from the review of these definitions is that the TOD is typically defined as a highly dense and mixed-use development around the transit station where the benefit of proximity to the station would promote transit usage rather than simply a planning strategy. The practice or the strategy itself can also be called TOD; moreover, it can be regarded that the term TOD can be synonymous with planning strategy, design, and development. The basic objective of the TOD is to reduce car dependence by reducing trip lengths as well as promoting the use of mass transit and sustainable modes, such as walking and cycling. The benefits that were achieved through the implementation of successful TOD projects include reduced traffic congestion, improved air quality, and affordable housing. Moreover, livable communities were created, sustainable transport was achieved, and the use of transit and non-motorized transport (NMT) as well as opportunities to live, work, shop, and relax

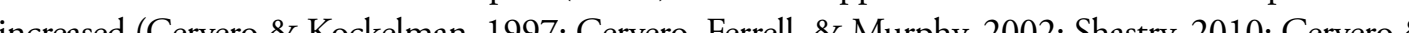
Ewing, 2014). The aforementioned definitions provide the basic features that are essential for developing the TOD. A variety of factors and their combinations are typically utilized to define and explain the TOD. These factors include the proximity to a transit station (based on distance or time), density levels, mixed land use, walking and cycling accessibility, effect of reducing car use, main travel mode, and the availability of public spaces to build communities (Cervero, 1997; Cervero, et al., 2002; Lund, Cervero, 
\& Wilson, 2004). Based on these definitions, a definition for the TOD is suggested in this review: $a$ urban planning strategy that aims to promote sustainable transport by creating more affordable housing and job availability by means of increased densification around mass transit stations. This especially developed area will have a mixed land use that supports a vibrant community life, and its extent will be determined by the types of mobility modes serving first or last-mile connectivity and area characteristics.

\section{Influence areas of TOD}

The influence area can be defined as the "area polarized by a center for a set of relations (influence are of a city) or a category of relations (area of cultural or commercial influence, trading area)" (Rodrigue, 2017); moreover, it is often described as the use of access distance and access time (or both) to transit. These specifications are further based on the various travel modes that are used for last-mile connectivity This section discusses the various means reported in literature to specify the influence area of the TOD. In literature, this area has been specified based on access distance, which directly provides the geographic extent of the TOD. A distance of $600 \mathrm{~m}$ (2000 ft) was introduced by Calthorpe $(1992,1993)$. Untermann (1984) and Dittamar and Ohland (2004) determined the distance as $800 \mathrm{~m}(1 / 2 \mathrm{mi})$. These (Cervero, Bern Cervero, Bernick, \& Jill, 1994; Bernick \& Cervero, 1997; Guerra, Cervero, \&Tischler, 2012). Guerr et al. (2012) raised doubts about the feasibility of adopting $800 \mathrm{~m}(1 / 2 \mathrm{mi})$ as the de facto standard for TOD in the United States as it is "more an artifact of historical precedent than a statistical or analytica construct". To determine the extent of TOD influence areas, some literature refer to a single distance, whereas it is reported that others use a distance range as basis. Guerra et al. (2012) and Flamm and Rivasplata (2014) emphasized that in the U.S, the radius of influence area can vary between 400 and $800 \mathrm{~m}(1 / 4-1 / 2 \mathrm{mi})$; consequently, various cities have adopted different radii for the TOD. In California, ordinances suppot the extent of the TOD projects to radii of 400,550, and $800 \mathrm{~m}(1 / 4,1 / 3$, and $1 / 2 \mathrm{mi}$, respective

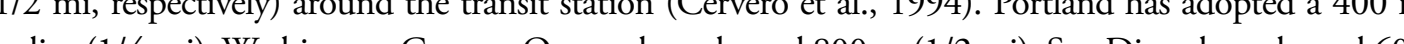
adius (1/4-mi); Washington County, Oregon has adopted $800 \mathrm{~m}$ (1/2 mi); San Diego has adopted 600 m (2000 ft), which is approximately $550 \mathrm{~m}$ (1/3) (Community Design + Architecture, 2001). Thes distances have also been expressed in terms of time. Researchers defined the extent of the TOD based o the distance that transit stations can be accessed by people within a specified time. Bernick and Cervero (1997) suggest that a 5-min walk corresponds to a $400 \mathrm{~m}$ (1/4-mi) distance. On the other hand, Calthorpe (1993) assumed that a 10 -min walk is equivalent to an $800 \mathrm{~m}(1 / 2$-mi) distance.

Few researchers have attempted to establish these distances based on empirical analysis. Guerra built station love direct demand models of transit ridership based on mgesson Lee (2015) used the walking time decay function to determine the willingness of people to walk. Zhao Chow, Li, and Gan (2003) combined both regression and distance decay methods to determine the accessibility levels around transit stations. In other cases, simple statistical methods, such as the mean o median (or both) distances and percentile distances were calculated to determine the influence areas of transit stations (Agrawal, Schlossberg, \& Ir, 2008; El-Geneidy, Grimsrud, Wasfi, Tétreault, \& Legault, 2014; Flamm \& Rivasplata, 2014). Most of these studies focused on walking as access mode (Agraw . Chia \& Lee 2015), whereas a few focused on cycling (Martens, 2004; Flamm \& Rivasplata, 2014). The results are summarized in Table 1.

Data availability and the accuracy of these data are crucial in performing such studies. Data regarding access and egress are not collected or are limited in most countries (Rietveld, 2000). In addition the distances reported by commuters often do not match the actual distances travelled. This is a poin Agrawal et al. (2008) highlighted; accordingly, their study also included a spatial analysis to measure the actual distances. Typically, commuters tend to round distances to some extent when responding to surveys. To overcome this drawback, route mapping with the use of geographic information system (GIS) is an effective approach. Otherwise, methods such as multiple imputation can be used to correct the rounded data (Heitjan \& Rubin, 1990; Drechsler \& Kiesl, 2016). In cases where origin-destina(El-Geneidy et al., 2014). 


\begin{tabular}{|c|c|c|c|c|c|c|c|}
\hline 訔 & 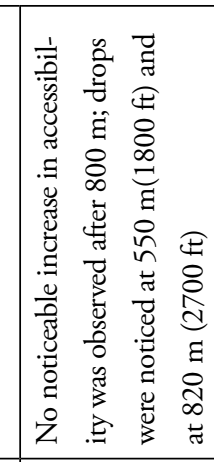 & 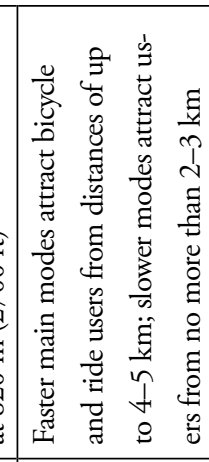 & 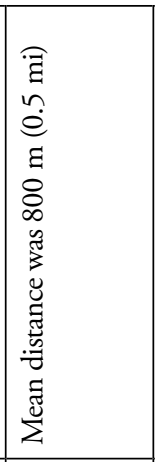 & 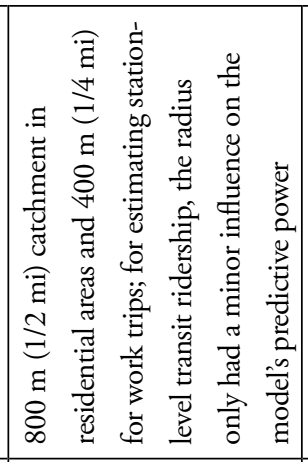 & 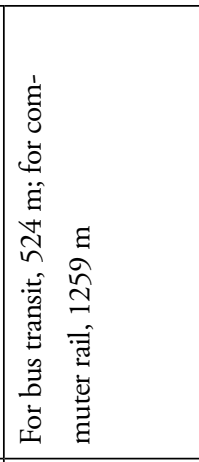 & 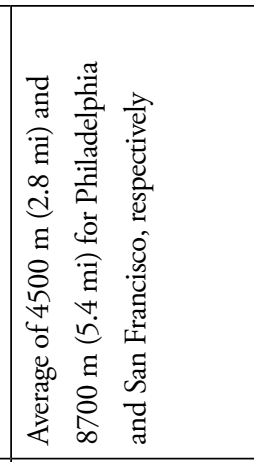 & 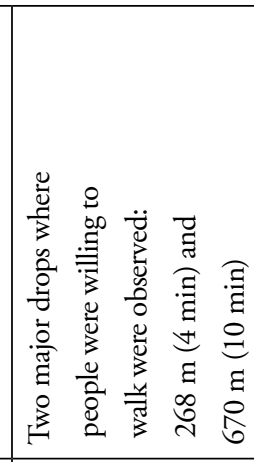 \\
\hline 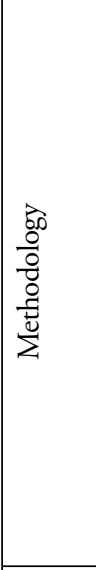 & 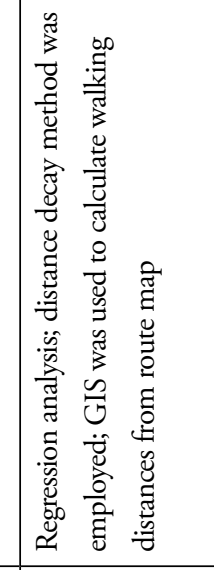 & 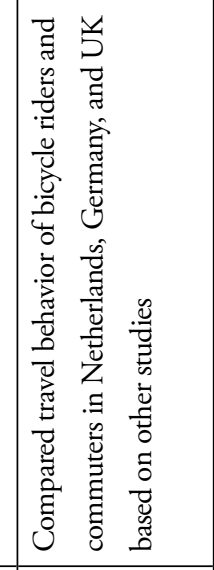 & 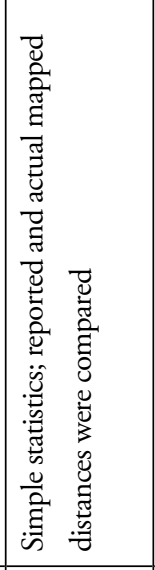 & 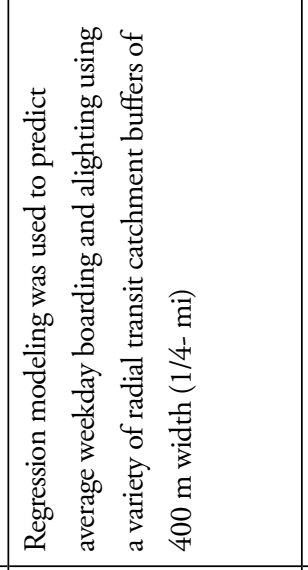 & 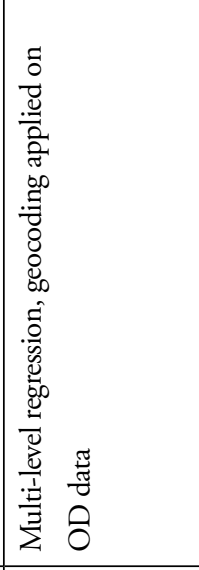 & 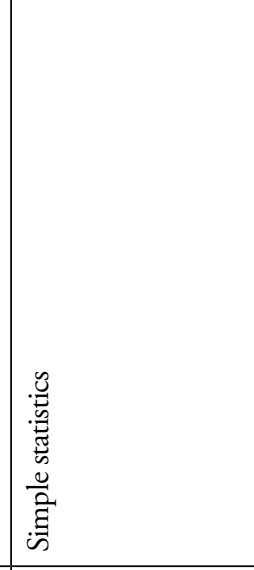 & 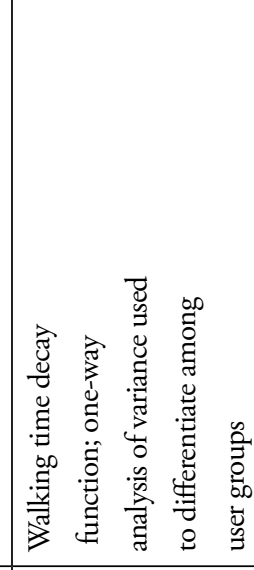 \\
\hline 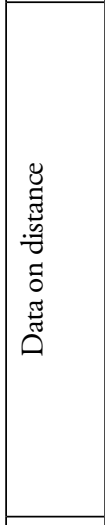 & 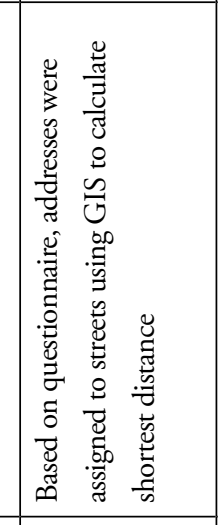 & 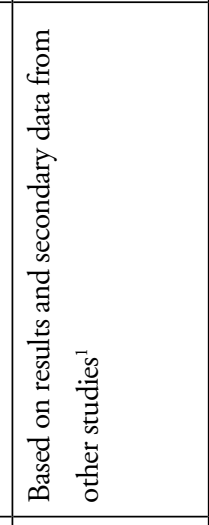 & 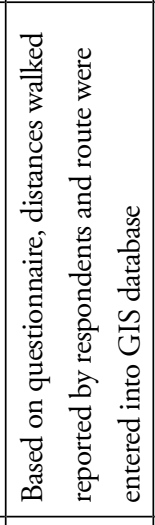 & 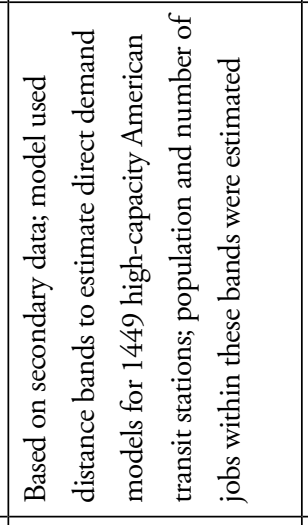 & 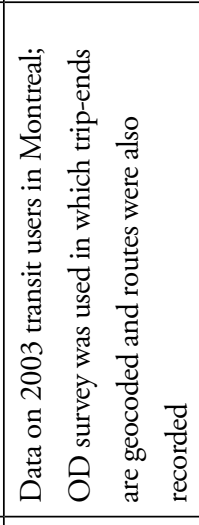 & 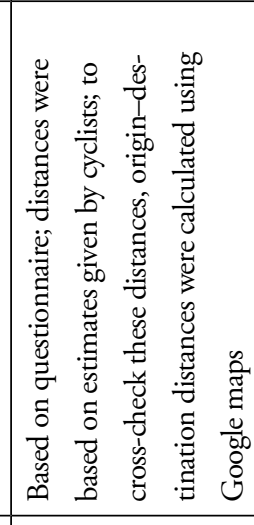 & 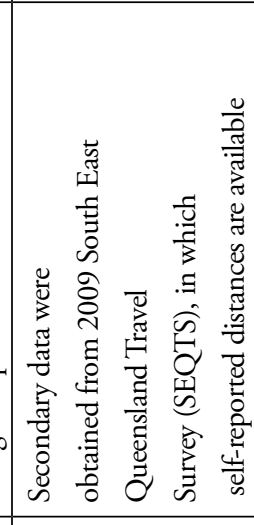 \\
\hline 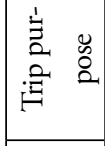 & ₹ & ₹ & ₹ & ₹ & ₹ & 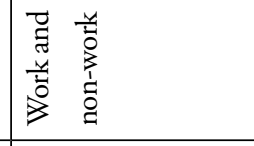 & ₹ \\
\hline 惫 & 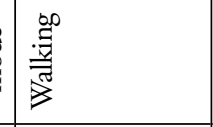 & 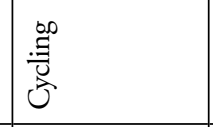 & 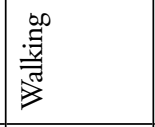 & 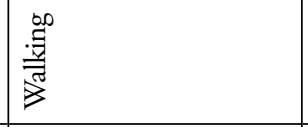 & 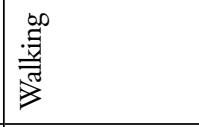 & 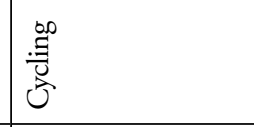 & 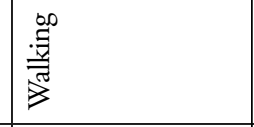 \\
\hline 氶 & 品䓂 & 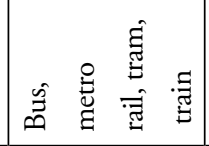 & 可 蒙 & 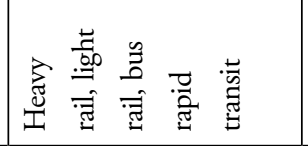 & 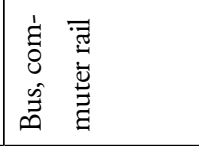 & 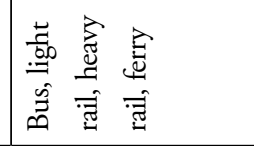 & 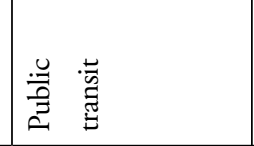 \\
\hline 竎 & 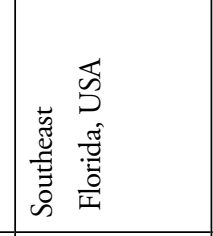 & 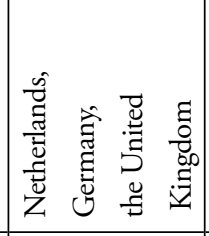 & 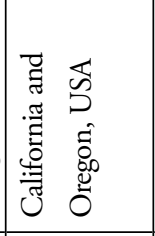 & 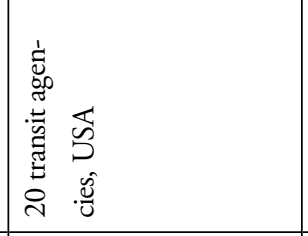 & 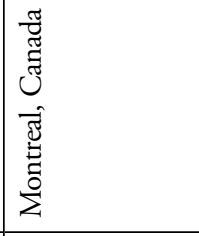 & 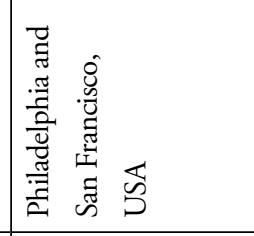 & 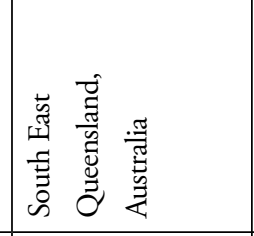 \\
\hline$\vec{Z}$ & 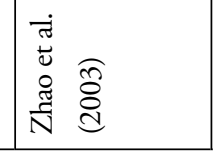 & 总 & 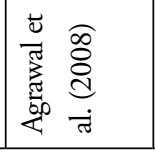 & 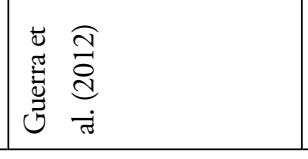 & 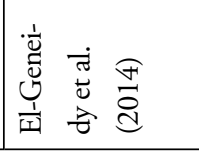 & 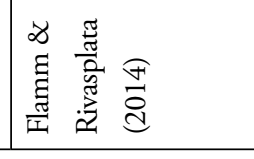 & 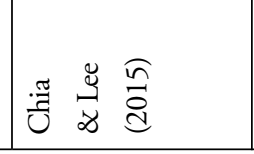 \\
\hline
\end{tabular}

Various researchers have suggested different radii or a range of acceptable distances based on empirical studies (Guerra et al., 2012; Park, Deakin, \& Jang, 2015). The standards for influence areas are based on walking as the access mode; these areas do not represent the catchment area of commuters who cycle, skate or use informal modes, such as auto rickshaws or pedi-cabs, for their first or last-mile connectivity. Cathorpe (1993), Bernick (he mode. The normally accepted radius of $800 \mathrm{~m}(1 / 2 \mathrm{mi})$ and other distances, such as 400,550 , and 1200 $\mathrm{m}(1 / 4,1 / 3$, or $3 / 4 \mathrm{mi}$, respectively), have been quoted in these aforementioned works bearing in mind the distance that "most" people are willing to walk to transit (Cervero et al., 1994; Bernick \& Cervero, 1997; Guerra et al., 2012). The half-mile $(800 \mathrm{~m})$ radius commonly represents the walk shed of pedestrians and has been derived based on the observation that most pedestrians are willing to walk $15 \mathrm{~min}$ to access transit stations at an average speed of $3.2 \mathrm{~km} / \mathrm{h}(2 \mathrm{mi} / \mathrm{h})$ (Agrawal et al., 2008). Unterman (1984) add that this distance is also dependent on whether the environment is conducive and plesent. , whe tue for European and Asin

There are researchers who have included other mobility options in explaining TODs but it is limited to bicycles. The distances covered by these modes are typically greater than the distances covered by walking. Studies conducted show that cyclists travel longer distances to reach transit stations than people who walk (Hochmair, 2013; Flamm \& Rivasplata, 2014; Lee et al., 2016). Flamm and Rivasplata (2014) examined the behavior of cyclists in Philadelphia and San Francisco and found that they

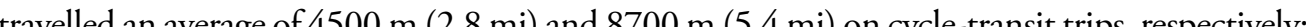
dicate lager atchments for bicyce ues. to increase the extent of TOD and its benefits. The study estimated the distances accessed by bicycles in Korean cities as 1.96 and $2.13 \mathrm{~km}$ for origin (home)-to-station and station-to-work trips, respectively This indicated that if a bicycle is used for planning the TOD, then $73.7 \%$ and $93.6 \%$ of the entire area of Seoul would be covered, whereas a conventional walking-only TOD can cover only $29.9 \%$ of the area. The catchment ranges of feeder buses and car (kiss and ride) was estimated in the range, approx. $2000-6000 \mathrm{~m}$ and approx. $1000-7000 \mathrm{~m}$ respectively (Gil \& Read, 2012); increasing the influence it should include other modes of last mile connectivity.

Currently, remedies are being implemented to resolve this problem. In their policy regarding pedestrian and bicycle mobility improvements (FTA, 2011), the Federal Transit Authority (FTA, USA) proposed $800 \mathrm{~m} \mathrm{(1/2} \mathrm{mi)} \mathrm{and} 2400 \mathrm{~m}(3 \mathrm{mi})$ for pedestrians and cyclists, respectively. This proposal revises the earlier $400 \mathrm{~m}(1500-\mathrm{ft})$ radius that considered only pedestrians. Additionally, the policy mentions that a $800 \mathrm{~m}(1 / 2 \mathrm{mi})$ radius is a conservative measure and the area can be extended assuring that people can walk safely and conveniently to reach the transit. Evidently, adherence to standards is not extremely strict. Hence, policy changes have been implemented in the past based on studies that reflect the last-mile mobility par eas based on walking bicycles and automobiles, thus emphaizing multimoda access to tranit station (DoT Maryland, 2000). Gutiérrez, Cardozo, \& Garcia-Palomares (2011) considered the importance of feeder buses for rail transit-based TODs. If modes other than walking can be considered, the distance can be effectively increased. Therefore, the commonly accepted standards may not be appropriate in cities where different access modes other than walking are used.

The use of different modes to access transit stations is especially relevant in urban and suburban areas. Literature also suggests that catchment areas have to be different based on the type of transit used (eithering been set to 400-800 m (Ker \& Ginn, 2003). Ker and Ginn (2003) indicated that commuters walked 
shorter distances to suburban stations $(800 \mathrm{~m})$ compared with distances covered to reach urban station $(1 \mathrm{~km})$. However, when delineating a catchment area, Cervero (1997) suggests that these catchmen areas in urban areas could be larger than those in suburban areas because of low residential densities and extensive parking spaces. Therefore, it can be deduced that even if people walk shorter distances to areas.

Various studies show that the size of influence zones is also based on the type of transit (main mode). The common understanding is that people walk more to access rail stations $(800 \mathrm{~m}$ or $1 / 2 \mathrm{mi})$ compared with the distance covered to access bus stations ( $400 \mathrm{~m}$ or $1 / 4 \mathrm{mi}$ ) (O'Sullivan \& Morral 1995; Morrall \& O'Sullivan, 1996; Gutiérrez \& Garcia Palomares, 2008; Zielstra \& Hochmair, 2011). However, opinions differ among researchers regarding these catchment area sizes. A guide published by Snohomish county indicates that commuters are generally willing to walk more to the rail transit $(400-550 \mathrm{~m}$ ) compared with accessing the bus transit, which is a $300 \mathrm{~m}$ (1000 ft) walk: this highights the difference in catchment areas based on the transit mode. In Ireland, the basic rule is that commuters are willing to walk $1 \mathrm{~km}$ to access rail stations (O'Connor \& Harrison, 2012).

The difference in catchment areas can be observed based on the type of rail transit (APTA, 2009). The APTA standards also indicate that transit ridership decreases as the distance from transit station increases; the standards adopted by APTA are summarized in Table 2.

\begin{tabular}{|c|c|c|c|c|c|}
\hline & $\begin{array}{c}\text { Local street } \\
\text { transit }\end{array}$ & $\begin{array}{c}\text { Rapid street } \\
\text { transit }\end{array}$ & $\begin{array}{c}\text { Semi rapid } \\
\text { transit }\end{array}$ & Regional transit & Rapid transit \\
\hline $\begin{array}{l}\text { Core station } \\
\text { area }\end{array}$ & NA & $\begin{array}{l}200 \mathrm{~m} \\
(1 / 8 \mathrm{mi})\end{array}$ & $\begin{array}{l}400 \mathrm{~m} \\
(1 / 4 \mathrm{mi})\end{array}$ & $\begin{array}{l}400 \mathrm{~m} \\
(1 / 4 \mathrm{mi})\end{array}$ & $\begin{array}{l}550 \mathrm{~m} \\
(1 / 3 \mathrm{mi})\end{array}$ \\
\hline $\begin{array}{l}\text { Primary } \\
\text { catchment area }\end{array}$ & $\begin{array}{l}200 \mathrm{~m} \\
(1 / 8 \mathrm{mi})\end{array}$ & $\begin{array}{l}400 \mathrm{~m} \\
(1 / 4 \mathrm{mi})\end{array}$ & $\begin{array}{l}800 \mathrm{~m} \\
(1 / 2 \mathrm{mi})\end{array}$ & $\begin{array}{l}800 \mathrm{~m} \\
(1 / 2 \mathrm{mi})\end{array}$ & $\begin{array}{l}1100 \mathrm{~m} \\
(2 / 3 \mathrm{mi})\end{array}$ \\
\hline $\begin{array}{l}\text { Secondary } \\
\text { catchment area }\end{array}$ & $\begin{array}{l}800 \mathrm{~m} \\
(1 / 2 \mathrm{mi})\end{array}$ & $\begin{array}{l}1600 \mathrm{~m} \\
(1 \mathrm{mi})\end{array}$ & $\begin{array}{l}3200 \mathrm{~m} \\
(2 \mathrm{mi})\end{array}$ & $\begin{array}{l}8000 \mathrm{~m} \\
(5 \mathrm{mi})\end{array}$ & $\begin{array}{l}4800 \mathrm{~m} \\
(3 \mathrm{mi})\end{array}$ \\
\hline
\end{tabular}

Hochmair (2013) suggests that this difference in catchment areas also applies to cyclists and specifies the distance as $1600 \mathrm{~m}(1 \mathrm{mi})$ and $3200 \mathrm{~m}$ (2 mi) for community hubs and gateway hubs, respectively. Additionally, certain studies show that based on trip purpose, the distance people walk or cycle to access transit stations can vary (Guerra et.al., 2012; Lee et.al., 2016). Therefore, it can be remarked tha a single standard or de facto value cannot be applied for determining the scale of TODs. The various influence areas based on different factors are summarized in Table 3 . It emphasizes that the adoption of a single standard for the influence area is not advisable.

\begin{tabular}{|c|c|}
\hline $\begin{array}{l}\text { Factors used for } \\
\text { defining TOD }\end{array}$ & Quantitative or Qualitative values assigned \\
\hline \multirow[t]{4}{*}{ Distance } & $-400 \mathrm{~m}$ (Bernick \& Cervero, 1997) \\
\hline & -800 m (Untermann, 1984; Dittamar \& Ohland, 2004; FTA, 2011) \\
\hline & $\begin{array}{l}\text {-400-800 m (Cervero et al., 1994; Cervero, 1997; Community Design + Architecture, 2001; Guerra et } \\
\text { al., 2012; Flamm \& Rivasplata, 2014) }\end{array}$ \\
\hline & -2000 ft or $600 \mathrm{~m}$ (Calthorpe, 1992, 1993) \\
\hline \multirow[t]{2}{*}{ Time } & -5-min walk (Bernick \& Cervero, 1997) \\
\hline & 10-min walk (Calthorpe, 1993) \\
\hline \multirow[t]{4}{*}{ Access mode } & $\begin{array}{l}\text { - Based on walk as access mode, distances vary from } 400 \text { to } 800 \text { m (Calthorpe, 1993, 1994; Cervero et al., } \\
\text { 1994; Bernick \& Cervero, 1997; Cervero, 1997; Untermann, 1984; Dittamar \& Ohland, 2004; Com- } \\
\text { munity Design + Architecture, 2001; Guerra et al., 2012; Flamm \& Rivasplata, 2014 }\end{array}$ \\
\hline & $-4800 \mathrm{~m}$ for cyclists (FTA, 2011) \\
\hline & $\begin{array}{l}4500 \mathrm{~m} \text { and } 8700 \mathrm{~m} \text { in Philadelphia and San Francisco for cyclists, respectively (Flamm \& Rivasplata, } \\
\text { 2014) }\end{array}$ \\
\hline & $\begin{array}{l}-1.96 \text { and } 2.13 \mathrm{~km} \text { for home-to-station and station-to-work trips for cyclists, respectively (Lee et al., } \\
2016 \text { ) }\end{array}$ \\
\hline Type of area & -Walkable catchment area in suburban areas, 400-800 m, and in urban areas, $1 \mathrm{~km}$ (Ker \& Ginn, 2003) \\
\hline \multirow[t]{4}{*}{ Main mode } & $\begin{array}{l}\text {-800-m access to rail station (Morrall \& O’Sullivan, 1996; Gutiérrez \& Garcia Palomares, 2008; Zielstra } \\
\text { \& Hochmair, 2011) }\end{array}$ \\
\hline & $-1 \mathrm{~km}$ access to rail station (O'Connor \& Harrison, 2012). \\
\hline & $\begin{array}{l}\text {-400-m access to bus station (Morrall \& O'Sullivan , 1996; Gutiérrez \& Garcia Palomares, 2008; Zielstra } \\
\text { \& Hochmair, 2011) }\end{array}$ \\
\hline & $\begin{array}{l}\text { - The primary catchment area for local street transit }(200 \mathrm{~m}) \text {, rapid street transit ( } 400 \mathrm{~m}) \text { ), semi-rapid tran- } \\
\text { sit and regional transit }(1 / 2 \mathrm{mi} \text { or } 800 \mathrm{~m} \text { ), and rapid transit }(2 / 3 \mathrm{mi} \text { or } 1100 \mathrm{~m})(\mathrm{APTA}, 2009)\end{array}$ \\
\hline \multirow[t]{3}{*}{ Trip purpose } & $\begin{array}{l}-800 \mathrm{~m} \text { catchment areas for home-based trips of residents and } 400 \mathrm{~m} \text { catchment areas for access to work } \\
\text { (Guerra et al., 2012) }\end{array}$ \\
\hline & $-1.96 \mathrm{~km}$ for origin (home)-to-station and $2.13 \mathrm{~km}$ for station-to-work trips for cyclists ( Lee et al., 2016) \\
\hline & $\begin{array}{l}\text {-150-300 } \mathrm{m} \text { for external employees and } 2400 \mathrm{~m} \text { for residents (City of Redmond Planning Commission, } \\
\text { 2014) }\end{array}$ \\
\hline
\end{tabular}

\section{TOD influence areas in Indian cities}

The TOD concept is not new to Asian countries; however, the term "TOD" may not have been used (Sung, 2011). Some researchers claim that the TOD in Asia has not been applied on the basis of sustainability; instead, it has been treated as a function of density and land shortage — a function that is yet to $b$ applied to the US or Australian cities (Kachi, Kato, \& Hayashi, 2005). In Japan, the concept is explored using the term "compact city" (Kachi et al., 2005). Seoul is another example of an Asian city with dense development characteristics: Hong Kong similarly illustrates such characteristics. Loo, Chen and Cho to study the rail-based TOD and take into consideration the difference between New York and Hon Kong. The study stressed that place-specific factors should be considered while examining railway patronage in different cities. Therefore, it can be deduced that the direction in which cities approach fac- 
tors, such as density, diversity, and design, varies according to the character and customs of a city and is essentially reflected in its mobility culture (Wilson, 2013).

In 2015, the Ministry of Urban Development of India gave notification pertaining to the National (TOD) Policy (MoUD, 2015) to promote sustainable urbanization in Indian cities. The cities have been advised to incorporate the TOD in their master and development plans and identify transit influence zones along transit corridors. The central government issued the TOD Guidance Document in May 2016 (MoUD, 2016) to facilitate the planning and implementation of TOD plans in cities. The TOD is also being promoted in the country through the 2017 Metro Policy (MoHUA, 2017a) and the proposed 2017 Green Urban Mobility Scheme (MoHUA, 2017b). Under the policy, the TOD has been made under the Green Urban Mobility Scheme, and the satisfaction of these criteria has been made a priority for receiving financial assistance in the development of metro infrastructures. The TOD guidance document asserts that the priority should not focus on increasing density, but on promoting NMT infrastructures, mixed land uses, and improving the first-and-last-mile connectivity pret-iented builings, and paking mar recified as a prerequin specified as a prequisite for the TOD becarse he of the TOD. Evidently, there is a necessity to adopt the TOD considering the different characteristic of the proposed areas.

The National Transit Oriented Development (TOD) Policy defines the influence zone of transit stations as walking distances of 500-800 $\mathrm{m}$ (i.e., 10-12-min walking distances) when the transit statio spacing is approximately $1 \mathrm{~km}$. When the distance between the transit stations is less than $1 \mathrm{~km}$, then the influence areas of adjacent stations overlap, and the influence zone becomes a delineated zone with radius of $500 \mathrm{~m}$. The ir ion, i.e., within a walking distance, having high density compact development with mixed land use to upport all basic requirements of the residents is called the influence zone of a transit station/ corridor" (MoUD, 2015). The policy calls for these zones to be clearly demarcated by responsible authorities based on supporting principles for its selection and should be verified through master plans and loca area plans before implementing the TOD project. The influence area standards adopted for some of the Indian cities are summarized in Table 4.

\begin{tabular}{|c|c|c|c|}
\hline & Influence area & Transit mode & Comments \\
\hline $\begin{array}{l}\text { National Transit } \\
\text { Oriented } \\
\text { Development } \\
\text { (TOD) Policy }\end{array}$ & $500-800 \mathrm{~m}$ & $\begin{array}{l}\text { Transit mode } \\
\text { not specified }\end{array}$ & $\begin{array}{l}\text { Delineated zone of } 500 \mathrm{~m} \text { is } \\
\text { specified on either side of transit } \\
\text { corridor when distance between } \\
\text { transit stations is less than } 1000 \mathrm{~m}\end{array}$ \\
\hline $\begin{array}{l}\text { TOD Guidance } \\
\text { document }\end{array}$ & \begin{tabular}{|l|} 
500-800 m, (10-min walk or \\
cycling), Buffer along transit line, \\
$400-1000 \mathrm{~m} \mathrm{(5-10-min} \mathrm{walk}$ \\
around stations), Individual \\
parcel within a 5-10-min \\
walking distance $(800-1000 \mathrm{~m})$ \\
from station
\end{tabular} & $\begin{array}{l}\text { MRTS, Public } \\
\text { transit } \\
\text { including buses }\end{array}$ & $\begin{array}{l}\text { Specifies influence area on } \\
\text { corridor and station area level }\end{array}$ \\
\hline New Delhi & \begin{tabular}{|l|} 
Intense zone $-300 \mathrm{~m}$, Standard \\
TOD zone $-800 \mathrm{~m}$ (10-min \\
walk), TOD transition zone - \\
$2000 \mathrm{~m}(10$-min cycling) \\
(UTTIPEC, 2012), Delhi Master \\
Plan 2021 specifies a belt with a \\
width of approximately $500 \mathrm{~m}$ on \\
both sides of MRTS corridor
\end{tabular} & MRTS, Metro & $\begin{array}{l}\text { Buffer on both sides of MRTS line, } \\
\text { Different scales for station areas, } \\
\text { Advise to conduct ped-shed analy- } \\
\text { sis }\end{array}$ \\
\hline Naya Raipur & $\begin{array}{l}400 \mathrm{~m} \text { (5-min walk) and } 800 \mathrm{~m} \\
\text { (10-min walk) }\end{array}$ & \begin{tabular}{|lr} 
Bus rapid \\
Transit & System \\
(BRTS)
\end{tabular} & $\begin{array}{l}\text { Circular buffer around transit sta- } \\
\text { tion }\end{array}$ \\
\hline Ahmedabad & $\begin{array}{l}200 \mathrm{~m} \text { - BRTS } \\
200 \mathrm{~m} \text { - Metro }\end{array}$ & BRTS, Metro & \begin{tabular}{|l}
$200-\mathrm{m}$ buffer on both sides of \\
transit route, local area plans \\
developed
\end{tabular} \\
\hline Mumbai & $\begin{array}{l}\text { Gateway zone - } 250 \mathrm{~m} \\
\text { Intermediate zone - } 500 \mathrm{~m} \\
\text { Outer zone }-1000 \mathrm{~m}\end{array}$ & $\begin{array}{l}\text { MRTS-Subur- } \\
\text { ban rail, metro }\end{array}$ & \\
\hline Cochin & $500 \mathrm{~m}$ buffer & Metro & $\begin{array}{l}\text { Buffer on both sides of MRTS line, } \\
\text { Pedestrian networks drawn for } \\
\text { each station; } 250 \mathrm{~m} \text { inner circles } \\
\text { for station area }\end{array}$ \\
\hline
\end{tabular}

The "half-mile radius" $(800 \mathrm{~m})$ is the de facto standard that is used in TOD plans, especially in the United States (Guerra et al., 2012). Although this standard, which is based on the willingness to walk, might be applicable to North American cities, it is necessary to determine whether it is applicable in the context of developing countries, such as India. A comparison of typical transport characteristics of various global cities has been shown in Table 5. The table highlights that the unlike other global cities Indian cities have existence of modes like auto rickshaws, cycle rickshaws, etc. which is not present in other cities. 
Table 5. Comparison of typical transport characteristics in cities

\begin{tabular}{|c|c|c|c|c|c|c|}
\hline City/country & Mode share & $\begin{array}{l}\text { Type of urban } \\
\text { transit }\end{array}$ & $\begin{array}{l}\text { Modes used for last } \\
\text { mile connectivity }\end{array}$ & Average GDP & $\begin{array}{l}\text { Cost of } \\
\text { monthly public } \\
\text { transport pass }\end{array}$ & $\begin{array}{l}\text { Average vehicle } \\
\text { ownership }\end{array}$ \\
\hline $\begin{array}{l}\text { New Delhi, } \\
\text { India }\end{array}$ & $\begin{array}{l}\text { Walking }(35 \%) \text {, bus (27\%), } \\
\text { two-wheelers (14\%), car/taxi } \\
(9 \%) \text {, auto rickshaw }(5 \%), \\
\text { bicyle (4\%), metro (3\%), } \\
\text { cycle rickshaw (2\%), sub } \\
\text { urban train }(1 \%) \text { (Report of } \\
\text { High Powered Committee } \\
\text { on how to decongest Delhi, } \\
2014) \\
\end{array}$ & $\begin{array}{l}\text { Bus, subway, sub- } \\
\text { urban rail (Report } \\
\text { of High Powered } \\
\text { Committee on how } \\
\text { to decongest Delhi, } \\
\text { 2014) }\end{array}$ & $\begin{array}{l}\text { Auto rickshaws, } \\
\text { cycle rickshaws, } \\
\text { electric rickshaws, } \\
\text { Gramin seva } \\
\text { (Ann et al., 2019), } \\
\text { taxis (Basu, } \\
\text { Varghese, \& Jana, } \\
\text { 2017) }\end{array}$ & $\begin{array}{l}\text { US } \$ 370 \\
\text { billion (2016) } \\
\text { (Deloitte, } \\
\text { 2019) }\end{array}$ & $\begin{array}{l}\text { US } \$ 22 \\
\text { (Deloitte, 2019) }\end{array}$ & $\begin{array}{l}\text { Approximately } 352 \\
\text { private vehicles per } 1000 \\
\text { persons (2018) } \\
\text { (calculated with data } \\
\text { from (Delhi government, } \\
\text { 2018) and (UNESCAP, } \\
\text { 2018) }\end{array}$ \\
\hline Mumbai, India & $\begin{array}{l}\text { Public transit }(70 \%) \text {, private } \\
\text { car }(14 \%) \text {, walking }(1 \%), \\
\text { bicycle }(2 \%) \text {, other }(13 \%) \\
\text { (Deloitte, 2019) }\end{array}$ & $\begin{array}{l}\text { Metro, bus, light } \\
\text { rail, commuter } \\
\text { train (Deloitte, } \\
\text { 2019) }\end{array}$ & \begin{tabular}{l|} 
Feeder buses (Em- \\
barq, 2014), auto \\
rickshaws, taxis \\
(Basu, Varghese, \& \\
Jana, 2017)
\end{tabular} & $\begin{array}{l}\text { US } \$ 416 \\
\text { billion (2017) } \\
\text { (Deloitte, } \\
\text { 2019) }\end{array}$ & $\begin{array}{l}\text { US } \$ 15 \\
\text { (Deloitte, 2019) }\end{array}$ & $\begin{array}{l}68 \text { cars per } 1000 \text { persons, } \\
122 \text { motorcycles per } \\
1000 \text { persons (2014) } \\
\text { Schiller \& Kenworthy, } \\
2017), 131 \text { vehicles per } \\
1000 \text { persons (calculated } \\
\text { with data from (Statista, } \\
\text { 2019) and (UN, 2016)) } \\
\end{array}$ \\
\hline Singapore & $\begin{array}{l}\text { Public transit }(44 \%) \text {, private } \\
\text { car }(29 \%) \text {, walking }(22 \%) \text {, } \\
\text { bicycle }(1 \%) \text {, other }(4 \%) \\
\text { (Deloitte, 2019) }\end{array}$ & $\begin{array}{l}\text { Metro, bus, ferry, } \\
\text { light rail (Deloitte, } \\
\text { 2019) }\end{array}$ & $\begin{array}{l}\text { Walking, bus, LRT } \\
\text { (Mo, Shen, \& } \\
\text { Zhao, 2018), bi- } \\
\text { cycle (Shen, Zhang, } \\
\& \text { Zhao, 2018) } \\
\end{array}$ & $\begin{array}{l}\text { US } \$ 296.9 \\
\text { billion (2016) } \\
\text { (Deloitte, } \\
\text { 2019) }\end{array}$ & $\begin{array}{l}\text { US } \$ 68 \\
\text { (Deloitte, 2019) }\end{array}$ & $\begin{array}{l}109 \text { private vehicles per } \\
1000 \text { persons (2018) } \\
\text { (calculated with data } \\
\text { from (LTA, 2018) and } \\
\text { (Statistics, 2018) } \\
\end{array}$ \\
\hline $\begin{array}{l}\text { Hong Kong, } \\
\text { China }\end{array}$ & $\begin{array}{l}\text { Public transit }(88 \%) \text {, private } \\
\text { car }(7 \%) \text {, walking }(3 \%), \\
\text { bicycle (2\%) (Deloitte, } 2019)\end{array}$ & $\begin{array}{l}\text { Metro, tram, bus, } \\
\text { ferry (Deloitte, } \\
\text { 2019) }\end{array}$ & $\begin{array}{l}\text { Light rail, bus, } \\
\text { mini bus, tram } \\
\text { (Transport Depart- } \\
\text { ment, 1998), car } \\
\text { (Govt. of Hong } \\
\text { Kong, 2018), } \\
\text { bicycle, walking }\end{array}$ & $\begin{array}{l}\text { US } \$ 326.4 \\
\text { billion (2017) } \\
\text { (Deloitte, } \\
\text { 2019) }\end{array}$ & $\begin{array}{l}\text { US } \$ 67 \\
\text { (Deloitte, 2019) }\end{array}$ & $\begin{array}{l}74 \text { motor vehicles per } \\
1,000 \text { people, } 56 \text { cars } \\
\text { per } 1000 \text { people (2009) } \\
\text { (Trading economics, } \\
2009) 82 \text { private cars per } \\
1000 \text { population (2019) } \\
\text { (calculated with data } \\
\text { from (CEIC, 2019) and } \\
\text { (Worldometers, 2019) } \\
\end{array}$ \\
\hline Tokyo, Japan & $\begin{array}{l}\text { Public transit }(19 \%) \text {, private } \\
\text { car }(45 \%) \text {, walking }(19 \%) \text {, } \\
\text { bicycle }(16 \%) \text {, other }(1 \%) \\
\text { (Deloitte, 2019) }\end{array}$ & $\begin{array}{l}\text { Metro, bus, ferry, } \\
\text { light rail, commut- } \\
\text { er rail (Deloitte, } \\
\text { 2019) }\end{array}$ & Walking, bicycle & $\begin{array}{l}\text { US } \$ 1.6 \text { tril- } \\
\text { lion (2017) } \\
\text { (Deloitte, } \\
\text { 2019) }\end{array}$ & $\begin{array}{l}\text { US } \$ 73 \\
\text { (Deloitte, 2019) }\end{array}$ & $\begin{array}{l}231 \text { automobiles per } \\
1000 \text { persons (Ministry } \\
\text { of Land, Infrastructur, } \\
\text { Transort and Tourism, } \\
\text { 2017) } \\
\end{array}$ \\
\hline Bogota, Brazil & $\begin{array}{l}\text { Public transit }(36 \%) \text {, private } \\
\text { car }(13 \%) \text {, walking }(46 \%) \text {, } \\
\text { bicycle (4\%), other }(1 \%) \\
\text { (Deloitte, 2019) }\end{array}$ & $\begin{array}{l}\text { Bus (Deloitte, } \\
\text { 2019) }\end{array}$ & $\begin{array}{l}\text { Bicycle (Deloitte, } \\
\text { 2019), walking }\end{array}$ & $\begin{array}{l}\text { US } \$ 159 \\
\text { billion (2014) } \\
\text { (Deloitte, } \\
\text { 2019) } \\
\end{array}$ & $\begin{array}{l}\text { US } \$ 40 \\
\text { (Deloitte, 2019) }\end{array}$ & \begin{tabular}{|l}
165 motor vehicles per \\
1000 persons (Secretaría \\
Distrital de Movilidad, \\
2013) \\
\end{tabular} \\
\hline
\end{tabular}

\begin{tabular}{|c|c|c|c|c|c|c|}
\hline $\begin{array}{l}\text { New York, } \\
\text { USA }\end{array}$ & $\begin{array}{l}\text { Public transit }(30 \%), \\
\text { private car }(33 \%) \text {, active } \\
\text { means }(38 \%, \text { including } \\
\text { bicycle }(1.3 \%)(\text { Steer, } 2019)\end{array}$ & \begin{tabular}{|l|} 
Buses, commuter \\
rail, light rail, \\
ferries, subway \\
(NYC Department \\
of City Planning, \\
2011)
\end{tabular} & \begin{tabular}{|l|} 
Walking, cars, \\
bicycle (Steer, \\
2019), taxis, \\
pedicabs (NYC \\
Department of \\
City Planning, \\
2011)
\end{tabular} & \begin{tabular}{|l} 
US $\$ 1275.14$ \\
billion \\
(Department \\
of Numbers, \\
2016)
\end{tabular} & \begin{tabular}{|l|} 
US $\$ 121$ \\
(Gothamist, \\
2017)
\end{tabular} & \begin{tabular}{|l|}
220 cars per 1000 \\
persons (New York City \\
Mobility Report, 2016), \\
430 vehicles per 1000 \\
persons (Newton, 2010)
\end{tabular} \\
\hline $\begin{array}{l}\text { Vancouver, } \\
\text { Canada }\end{array}$ & $\begin{array}{l}\text { Public transit }(14 \%) \text {, private } \\
\text { car }(72 \%) \text {, walking }(10 \%), \\
\text { bicycle }(2 \%) \text {, other }(2 \%) \\
\text { (Deloitte, 2019) }\end{array}$ & \begin{tabular}{|l} 
Bus, metro, ferry, \\
commuter rail \\
(Deloitte, 2019)
\end{tabular} & \begin{tabular}{|l} 
Walking, bicycles \\
(Kenneth, 2019)
\end{tabular} & $\begin{array}{l}\text { US } \$ 129.9 \\
\text { billion (2016) } \\
\text { (Deloitte, } \\
\text { 2019) }\end{array}$ & \begin{tabular}{|l|} 
US $\$ 133$ \\
(Deloitte, 2019)
\end{tabular} & $\begin{array}{l}111 \text { vehicles per } 1000 \\
\text { persons (Citified.CA } \\
\text { Staff, 2018) }\end{array}$ \\
\hline $\begin{array}{l}\text { Copenhagen, } \\
\text { Denmark }\end{array}$ & $\begin{array}{l}\text { Public transit (27\%), private } \\
\text { car (26\%), walking (6\%), bi- } \\
\text { cycle (41\%) (Deloitte, } 2019)\end{array}$ & \begin{tabular}{|l|} 
Metro, bus, \\
commuter rail \\
(Deloitte, 2019)
\end{tabular} & \begin{tabular}{|l|} 
Walking, bicycle, \\
car, bus (Halldórs- \\
dóttir, Nielsen, \& \\
Prato, 2017) \\
\end{tabular} & $\begin{array}{l}\text { US \$122 } \\
\text { billion (2016) } \\
\text { (Deloitte, } \\
\text { 2019) }\end{array}$ & \begin{tabular}{|l|} 
US $\$ 106$ \\
(Deloitte, 2019)
\end{tabular} & $\begin{array}{l}291 \text { cars per } 1000 \\
\text { persons (Copenhagenize. } \\
\text { com, 2012) }\end{array}$ \\
\hline $\begin{array}{l}\text { London, } \\
\text { United } \\
\text { Kingdom }\end{array}$ & $\begin{array}{l}\text { Public transit (49\%), private } \\
\text { car (26\%), walking }(20 \%), \\
\text { bicycle (5\%) (Deloitte, 2019) }\end{array}$ & $\begin{array}{l}\text { Metro, tram, bus, } \\
\text { commuter rail, } \\
\text { ferry, bicycle (De- } \\
\text { loitte, 2019) } \\
\end{array}$ & \begin{tabular}{|l} 
Walking, bicycle, \\
taxi, bus (Network \\
Rail, 2011)
\end{tabular} & $\begin{array}{l}\text { US } \$ 831 \\
\text { billion (2016) } \\
\text { (Deloitte, } \\
\text { 2019) }\end{array}$ & \begin{tabular}{|l|} 
US $\$ 195$ \\
(Deloitte, 2019)
\end{tabular} & $\begin{array}{l}300 \text { cars per } 1000 \\
\text { persons (Transport for } \\
\text { London, 2012) }\end{array}$ \\
\hline $\begin{array}{l}\text { Amsterdam, } \\
\text { Netherlands }\end{array}$ & $\begin{array}{l}\text { Public transit (17\%), private } \\
\text { car (20\%), walking (29\%), } \\
\text { bicycle (32\%), other (2\%) } \\
\text { (Deloitte, 2019) }\end{array}$ & $\begin{array}{l}\text { Metro, bus, ferry, } \\
\text { tram, commuter } \\
\text { train (Deloitte, } \\
\text { 2019) }\end{array}$ & $\begin{array}{l}\text { Walking, bicycle, } \\
\text { public transport } \\
\text { (bus/tram/metro to } \\
\text { and from rail tran- } \\
\text { sit) (Meng, Koh, \& } \\
\text { Wong, 2016) - for } \\
\text { Netherlands } \\
\end{array}$ & $\begin{array}{l}\text { US } \$ 121 \\
\text { billion (2013) } \\
\text { (Deloitte, } \\
\text { 2019) }\end{array}$ & \begin{tabular}{|l|} 
US $\$ 108$ \\
(Deloitte, 2019)
\end{tabular} & $\begin{array}{l}247 \text { cars per } 1000 \\
\text { persons (Central Bureau } \\
\text { voor de Statistiek, 2014) }\end{array}$ \\
\hline $\begin{array}{l}\text { Sydney, } \\
\text { Australia }\end{array}$ & $\begin{array}{l}\text { Public transit }(25 \%) \text {, private } \\
\text { car }(59 \%) \text {, walking }(4 \%) \text {, } \\
\text { bicycle (3\%), other }(9 \%) \\
\text { (Deloitte, 2019) }\end{array}$ & \begin{tabular}{|l|} 
Commuter rail, \\
light rail, bus, ferry \\
(Deloitte, 2019)
\end{tabular} & \begin{tabular}{|l|} 
Walking, bicycle, \\
buses, cars, taxi \\
(Charles \& Galiza, \\
2013)
\end{tabular} & $\begin{array}{l}\text { US } \$ 123 \\
\text { billion (2015) } \\
\text { (Deloitte, } \\
\text { 2019) }\end{array}$ & \begin{tabular}{|l|} 
US $\$ 129$ \\
(Deloitte, 2019)
\end{tabular} & $\begin{array}{l}720 \text { motor vehicles per } \\
1000 \text { persons aged } \\
18-84 \text { in private } \\
\text { dwellings (Charting } \\
\text { transport, 2016) }\end{array}$ \\
\hline $\begin{array}{l}\text { Melbourne, } \\
\text { Australia }\end{array}$ & $\begin{array}{l}\text { Public transit }(16 \%) \text {, private } \\
\text { car }(72 \%) \text {, walking }(3 \%) \text {, } \\
\text { bicycle }(2 \%) \text {, other }(7 \%) \\
\text { (Deloitte, } 2019)\end{array}$ & \begin{tabular}{|l|} 
Commuter train, \\
tram, bus (Deloitte, \\
2019)
\end{tabular} & \begin{tabular}{|l} 
Bus, tram, car, \\
bicycle (Galiza \& \\
Charles, 2013), \\
walking
\end{tabular} & $\begin{array}{l}\text { US } \$ 303.6 \\
\text { billion (2015) } \\
\text { (Deloitte, } \\
\text { 2019) }\end{array}$ & \begin{tabular}{|l|} 
US $\$ 111$ \\
(Deloitte, 2019)
\end{tabular} & $\begin{array}{l}800 \text { motor vehicles per } \\
1000 \text { persons aged } \\
18-84 \text { in private } \\
\text { dwellings (Charting } \\
\text { transport, 2016) } \\
\end{array}$ \\
\hline
\end{tabular}


In Indian cities, walking has a high share in the overall modal share, and people tend to walk longe distances (Embarq, 2014). Moreover, differences in the average walking distances across various cities should also be considered. However, the lack of adequate data and studies pertaining to Indian cities mainly limits the examination of this walking culture and the access-egress patterns; a few studies could be found to determine the walking or cycling distances in Indian cities. The NMT studies conducted in cities of Mumbai and Tiruchirapalli show that the willingness to wi $\mathrm{m}$, respectively, whereas the willingness to cycle was $2724 \mathrm{~m}$ in Mumbai, $5200 \mathrm{~m}$ in Tiruchirapalli, and $5100 \mathrm{~m}$ in Delhi (Arasan, Rengaraju, \& Krishna Rao 1994; Rastogi, 2011). Only a few studies have been conducted in cities, such as Mumbai and Delhi, to determine the distances that people walk to access transit stations. Rastogi (2010) performed studies in Mumbai to examine the distances that people have walked and cycled to access suburban rail. The acceptable walking and bicycling distances to reach the transit access environment were found to be $1250 \mathrm{~m}$ for $80 \%$ of the commuters (Rastogi \& Rao, 2003; Rastogi, 2010). Johar, Jain, Garg, and Gundaliva (2015) studied the distances walked by com(based on lognormal distribution) were 677, 660, 654, and $637 \mathrm{~m}$ for shopping, recreation, education and work trips, respectively. Research shows that commuters walk longer distances to access rail transi than reaching the bus transit (O’Sullivan \& Morrall, 1995; Morrall \& O'Sullivan, 1996; Gutiérrez \& Garcia Palomares, 2008; Zielstra \& Hochmair, 2011); therefore, it can be assumed that commuter walk longer distances to reach metro stations in Delhi. These results indicate that the assumed standard of $500 \mathrm{~m}$ in the TOD guideline has to be rechecked and it cannot be used as a common standard because the distances that people are willing to walk vary among cities. This can be done by conducting detailed studies on the last-mile-connectivity walking patterns of commuters.

Indian cities also have numerous types of travel modes, such as auto rickshaws, cycle-rickshaws, electric rickshaws, gramin sevas, and minivans, which are not employed in developed countries; some of these modes are shown in Fig. 2. These informal transport modes (or para transit or intermediate public transport modes) and their systems of operation perform a considerably important function in India cities. These modes are highly acclaimed by the public in Indian cities because they flexibly evolve by themselves to satisfy local and specialized requirements. They frequently provide multiple options in terms of modes, types of services, and fares to meet the mobility requirements of commuters in cities. Studies also show that in developing cornties, the commuters habitually tend to use availabl inform ransport modes for distances that could be easily covered by cycling and walking (Guillen, Ishida, \& Okamoto, 2013); this highlights the convenience of these modes. It has been shown that passenger who use informal transport modes like pedi-cabs tend to travel approximately $1 \mathrm{~km}$ longer than people who walk. (Fillone \& Mateo-Babiano, 2018). Compared with cities in developed countries where walking and cycling are the predominant modes for last-mile connectivity, a considerable size of the population in Indian cities relies on these informal modes to reach transit stations. In such cases, planning and policy making need to include these modes into last mile connectivity and overall planning and develop adequate infrastructure.

However, the standards that have been adopted tend to ignore the multimodal nature of Indian cities. In Mumbai, informal modes account for approximately $31 \%$ of the mode shares for access trip and $25 \%$ of the mode shares for egress trips (Rastogi \& Rao, 2003). In their study in Mumbai, Rastogi and Rao (2003) found that auto rickshaws or taxis accounted for $10 \%$ of the access trips, and for disances longer than $1250 \mathrm{~m}$ from suburban rail stations, these modes accounted for $16.5 \%$ of the access trips. A report published by Embarq (2014) proposed that a radius of 150-250 $\mathrm{m}$ (5-min walk) for the pedestrian priority area (primary area), a radius of $500-700 \mathrm{~m}$ for pedestrian and cyclist priority area (secondary area) and the radius of the catchment area will depend on the areas served by informal port and route lengths of feeder bus services; highlighting the need to include these modes for station area planning. It is necessary to study these modes to understand the functions they perform in access or egress trips and the influence they exert on the TOD.

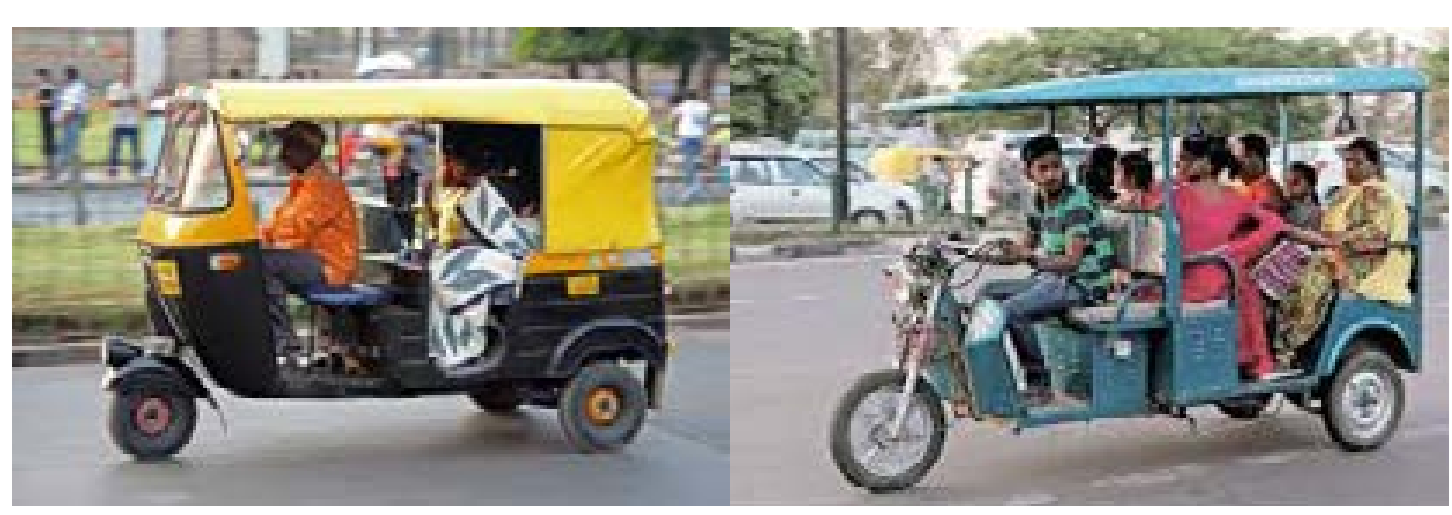

(a)

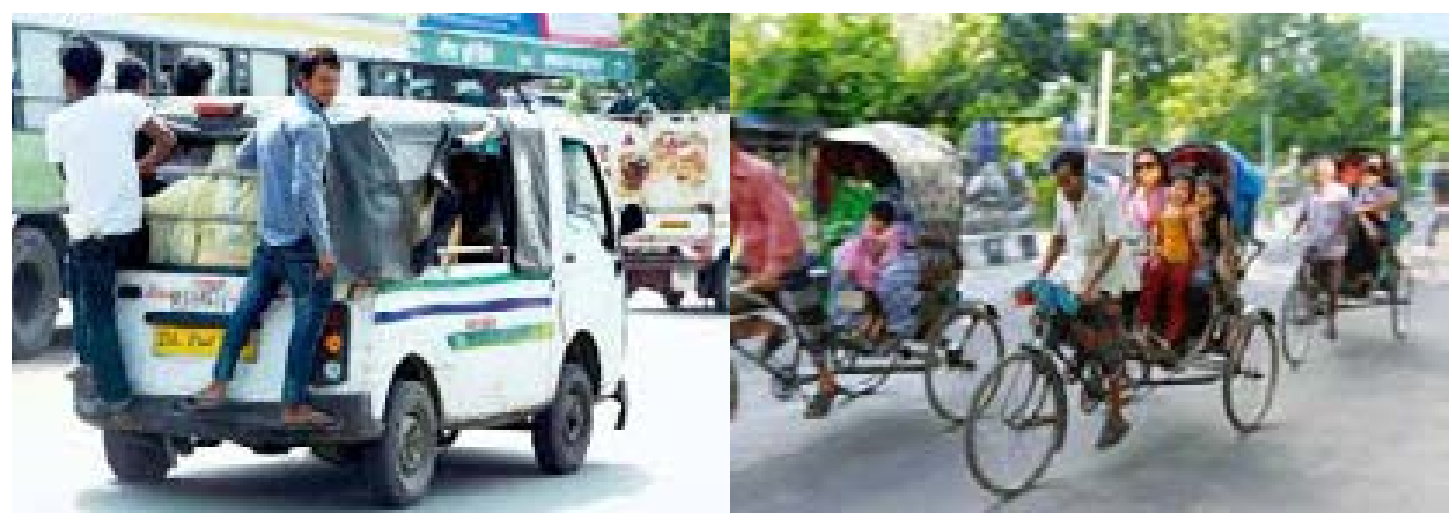

(c)

(d)

2. Examples of fifom modes avaluble in New Delhi: a) Auto rickshow b) E rickshaw c) Gramin seva, d) Cycle rickshaw

(Source: a. www.wikipedia.org, b. www.ndtv.com, c. www.dailymail.co.uk, d. www.livemint.com)

A survey conducted by Delhi Metro Rail Corporation (DMRC) in 2015 for metro stations show that after walking, informal modes are the most preferred access modes for the last-mile connectivity to reach metro stations; the survey results are shown in Fig. 3 and 4 . Fig. 3 shows the share of various access and egress modes; walking and informal modes are the most preferred modes. Fig. 4 shows the distribution of walking distances. 


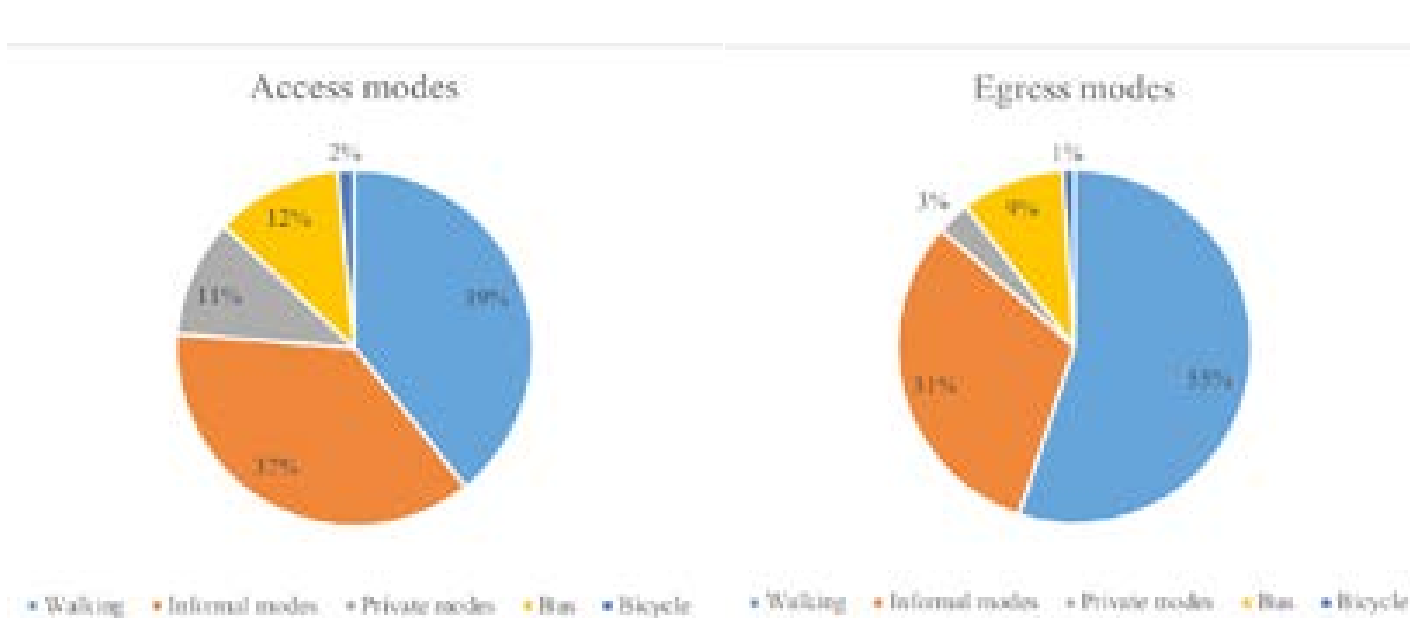

Figure 3. Modes used for access and egress to metro stations in New Delhi

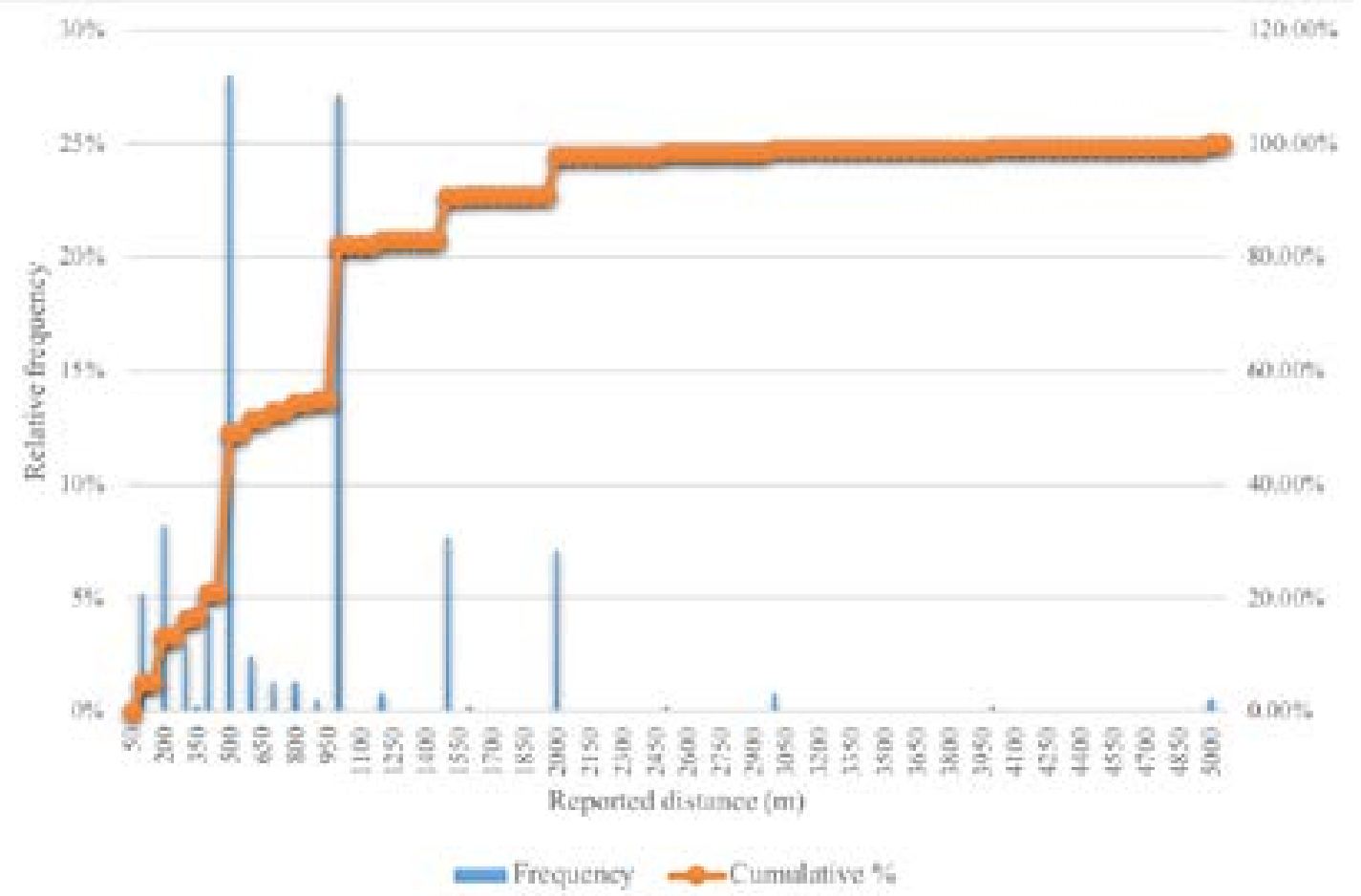

Figure 4. Distribution of reported distances for access by walking

The analysis of the data has been shown in Table 6. The mean walking distances are in the range of 700-800 for both access and egress. This matches the 500-800 m standard given in the National Transit Oriented Development (TOD) Policy and TOD Guidance document. However, the mean distances are much higher for informal modes, bus and private modes. Hochmair (2013) and El-Geneidy et al (2014) use the 85th percentile value to calculate catchment areas around transit stations for walking and cycling and the 85th percentile distance for walking for access and egress is $1000 \mathrm{~m}$; further extending the spatial extent of influence areas of transit stations than specified in the policy. Detailed research need to be carried out to find the threshold of last mile distances by different modes.
Table 6. Summary of travel distances

\begin{tabular}{|l|c|c|c|c|c|c|c|}
\hline \multirow{2}{*}{$\begin{array}{l}\text { Last mile distances } \\
\text { (in meters) }\end{array}$} & \multicolumn{5}{|c|}{ Access } & \multicolumn{3}{c|}{ Egress } \\
\hline & Walking & Informal modes & Bus & Private modes & Walking & Informal modes & Bus \\
\hline Minimum & 100 & 500 & 500 & 500 & 50 & 400 & 500 \\
\hline Maximum & 5000 & 20000 & 35000 & 40000 & 5000 & 15000 & 35000 \\
\hline Mean & 800 & 3300 & 6600 & 5500 & 700 & 3200 & 7100 \\
\hline Median & 600 & 2500 & 4000 & 3000 & 500 & 2000 & 3500 \\
\hline 75th percentile & 1000 & 4000 & 8000 & 6000 & 1000 & 4000 & 7000 \\
\hline 80th percentile & 1000 & 5000 & 10000 & 8000 & 1000 & 4000 & 10000 \\
\hline 85th percentile & 1500 & 5000 & 12000 & 12000 & 1000 & 5000 & 12000 \\
\hline
\end{tabular}

Evidently, few studies determine whether the TOD standards formulated by developed countries are appropriate for Indian cities. Moreover, the applicability of a common standard has to be verified because each city is different in terms of mobility characteristics. The current walking mobility culture in Indian cities has to be thoroughly examined in relation to the TOD planning. The informal modes have the capacity to ensure better public transit services (Kumar, Singh, Ghate, Pai, \& Wilson, 2016) have the capacity to ensure better public transit services (Kumar, Singh, Ghate, Pai, \& Wilson, 2016)
and therefore have the potential to facilitate the TODs. The function of informal transport and feeder buses to reach transit stations has to be considered in determining influence zones.

\section{Conclusion and future direction}

This review provides insight on the gap between the theoretical and scientific establishment of standards for transit catchment areas and the TOD influence areas. Existing studies show that the size of the influence area varies among different cities; it also varies with different access modes. Evidently, a single influence zone size is not suitable for all cases. In developed countries, the TOD influence area has been primarily formulated based on walking as the main access mode. Even though cycling is also a predominant access mode, it has been deemed insignificant in the planning practice. Because there is a predominant access mode, it has been deemed insignificant in the planning practice. Because there is no consensus among researchers on whether the half-mile radius is the appropriate distance for catch-
ment areas, such a criterion should be carefully examined in the planning of TODs in Indian cities. It ment areas, such a criterion should be carefully examined in the planning of TODs in Indian cities. I
holds for most of cities in India whose walking mobility patterns vary compared with those of developed countries. Accordingly, it is proposed that the local characteristics of cities be carefully studied in relation to the influence zone of the TODs. Moreover, it is not advisable for cities in India to consider only the walk-based TODs. This is because hast-mile travel patterns are multimodal Therefore these multimodes area of TOD can be defined is difficult because the last-mile connectivity of cities, various mobility modes used, trip purpose, travel distances, time taken to reach the transit station and the type of transit itself have to be analyzed in detail. It is necessary to examine the adequate size of the influence area in Indian cities by considering the characteristics of each city.

The practical implication of this research is that current planning practices may have to be reviewed to take into consideration of actual environments. The standards given in literature can only be used as initial reference. It is ideal to recommend to city authorities that extensive studies on existing condition be conducted. These may be implemented in the form of surveys to identify the mobility modes that are used by the public. These modes include walking, cycling, and the use of auto rickshaw to access o are used by the public. These modes include walking, cycling, and the use of auto rickshaw to access or
egress mass transit modes in the city. Therefore, insight on actual conditions can be gained. The current egress mass transit modes in the city. Therefore, insight on actual conditions can be gained. The current
necessity is to derive a methodology that can be used to analyze and extract the last-mile-connectivity necessity is to derive a methodology that can be used to analyze and extract the last-mile-connectivity
distances for mass transit influence zones of different cities. It should also be noted that these distances will vary across cities and within the zones of a city, depending on the type of main transit mode and the station area characteristics. 
The future work of this research is to focus on Indian cities with mass transit systems to understand the last-mile connectivity to transit stations and its impact on determining the influence zones for the TOD along the transit lines. Therefore, this future work aims to link the influence of actual mobility patterns to the TOD policies and guidelines in the country. The research will further examine the existing informal tranport culture along with the NMT in Indian cities, their contribution to last-mile conin (a) to analyze the tavel choice behavior of individuals on acceptable access modes and distances covered by different modes is necessary to obtain a city level guidance for the TOD planning. All of these would be beneficial for cities in India and other developing countries that intend to implement the TOD.

\section{References}

Agrawal, A. W., Schlossberg, M., \& Ir, K. (2008). How far, by which route and why? A spatial analysis of pedestrian preference. Journal of Urban Design, 13(1), 81-98.

APTA. (2009). Defining transit areas of influence (APTA SUDS-UD-RP-001-09). Washington, DC American Public Transportation Association.

Arasan, V., Rengaraju, R., \& Krishna Rao, K. (1994). Characteristics of trips by foot and bicycle modes in Indian city. Journal of Transportation Engineering, 120(2), 283-294.

Arrington, G., \& Cervero, R. (2008). Effects of TOD on housing, parking, and travel. (TCRP report 128) Washington, DC: Transportation Research Board.

Bernick, M., \& Cervero, R. (1997). Transit villages for the 21st century. New York: McGraw Hill.

Bickelbacher, P. (2001). Bericht zur Vorheruntersuchung im MOBINET arbeitspaket A4 bike + ride. Munchen: SRL/SSP.

Boarnet, M., \& Crane, R. (1998). L. A. story: A reality check for transit-based housing. Journal of the American Planning Association, 63(2), 189-204.

Calthorpe, A. (1992). Transit-oriented development design guidelines (Resolution no. R-280480). San Diego: Planning Department, City of San Diego.

Calthorpe, P. (1993). The next American metropolis: Ecology, community and the American dream. New Jersey: Princeton Architectural Press.

Carlton, I. (2007). Histories of transit-oriented development: Perspectives on the development of the TOD concept (WP-2009-02). Berkeley, CA: University of California.

Cervero, R. (1997). Rail access modes and catchment areas for the BART System. Berkeley, CA: University of California Transportation Center (UCTC).

Cervero, R. (2009). Public transport and sustainable urbanism: Global lessons. In J. L. Renne (Ed.), Transit oriented development — making it happen. London: Routledge.

Cervero, R., Bernick, M., \& Jill, G. (1994). Market opportunities and barriers to transit-based developmen in California (working paper). Berkeley, CA: University of California Transportation Center.

Cervero, R., \& Ewing, R. (2014). Travel and the built environment: A Synthesis. Transportation Research Record: Journal of the Transportation Research Board, 1780. doi.10.3141/1780-10

Cervero, R., \& Kockelman, K. (1997). Travel demand and the 3Ds: Density, diversity, and design Transportation Research Part D: Transport and Environment, 2(3), 199-219.

Cervero, R., Ferrell, R., \& Murphy, S. (2002). Transit-oriented development and joint development in the United States: A literature review. Research Results Digest, 52, 1-144.

Chia, J. C., \& Lee, J. B. (2015). Variation in the walking time to bus stop by the degree of transit captivity. Australasian Transport Research Forum Proceedings. Retrieved from http://www.atrf.info/papers/ index.aspx.

City of Redmond Planning Commission. (2014, March 19). www.remond.gov. Retrieved from http:// www.redmond.gov/common/pages/UserFile.aspx?fileId=122774

Community Design + Architecture, I. (2001). Model transit-oriented district overlay zoning ordinance. Oakland, CA: Valley Connections.

Dittamar, H., \& Ohland, G. (2004). The new transit town — best practices in transit oriented development Washington, DC: Island Press.

DOT California. (2001). Factors for success in Californias transit-oriented development. Sacramento, CA California Department of Transportation, Technical Advisory and Policy Steering Committee.

DOT Maryland. (2000). Report to Governor Parris N. Glendening from the Transit-Oriented Development Task Force. Hanover, MD: Maryland Department of Transportation. 
Drechsler, J., \& Kiesl, H. (2016). Beat the heap: An imputation strategy for valid inferences from rounded income data. Journal of Survey Statistics and Methodology, 4, 22-42.

El-Geneidy, A., Grimsrud, M., Wasfi, R., Tétreault, P., \& Legault, S. (2014). New evidence on walking distances to transit stops: Identifying redundancies and gaps using variable service areas. Transportation, $41(1), 193-210$

Embarq. (2014). Safe access to mass transit stations in Indian cities. In Safe access manual (Vol-1). New Delhi: WRI India.

Fillone, A. M., \& Mateo-Babiano, I. (2018). Do I walk or ride the rickshaw? Examining the factors affecting first- and last-mile trip options in the historic district of Manila (Philippines). Journal of Transport and Land Use, 11(1), 237-254.

Flamm, B., \& Rivasplata, C. (2014). Public transit catchment areas—-the curious case of cycle-transit users. Transportation Research Record: Journal of the Transportation Research Board, 2419, 101-108.

FTA. (2011). Final policy statement on eligibility of pedestrian and bicycle improvements - summary (Federal Register - FTA - 2009—0052). Washington, DC: Federal Transit Authority

Gil, J., \& Read, S. (2012). Measuring sustainable accessibility potential using the mobility infrastructure's network configuration. Eighth International Space Syntax Symposium, Santiago de Chile.

Guerra, E., Cervero, R., \& Tischler, D. (2012). The half-mile circle: Does it best represent transit station catchments? Transportation Research, 2276, 101-109.

Guillen, M. D., Ishida, H., \& Okamoto, N. (2013). Is the use of informal public transport modes in developing countries habitual? An empirical study in Davao City, Philippines. Transport Policy, 26, $31-42$.

Gutiérrez , J., \& Garcia Palomares, J. (2008). Distance-measure impacts on the calculation of transport service areas using GIS. Environment and Planning B: Planning and Design, 35(3), 480-503.

Gutiérrez, J., Cardozo, O. D., \& Garcia Palomares, J. C. (2011). Transit ridership forecasting at station level: An approach based on distance-decay weighted regression. Journal of Transport Geography, 19, 1081-1092.

Heitjan, D. F., \& Rubin, D. B. (1990). Inference from coarse data via multiple imputation with application to age heaping. Journal of American Statistical Association, 85(410), 304-314.

Hochmair, H. (2013). Assessment of bicycle service areas around transit stations. International Journal of Sustainable Transportation, 1(1), 15-29.

Jiang, Y. P. (2012). Walk the line: Station context, corridor type, and bus rapid transit walk access in Jinan, China. Journal of Transport Geography, 20(1), 1-14.

Johar, A., Jain, S., Garg, P., \& Gundaliya, P. (2015). A study for commuter walk distance from bus stop to different destinations along routes in Delhi. European Transport Issue, 59, 1825-3997.

Kachi, N., Kato , H., \& Hayashi, Y. (2005). Making cities more compact by improving transport and amenity and reducing hazard. Journal of the Eastern Asia Society for Transportation Studies, 6 3819-3834.

Ker, I., \& Ginn, S. (2003). Myths and realities in walkable catchments: The case of walking and transit. Road \& Transport Research, 12(2), 69-80.

Kumar, M., Singh, S., Ghate, A. T., Pal, S., \& Wilson, S. A. (2016). Informal public transport modes in India: A case study of five city regions. IATSS Research, 39(2), 102-109.

Lee, J., Choi , K., \& Leem, Y. (2016). Bicycle-based transit-oriented development as an alternative to overcome the criticisms of the conventional transit-oriented development. International Journal of Sustainable Transportation, 10(10), 975-984.

Loo, B., Chen, C., \& Chan, E. (2010). Rail-based transit-oriented development: Lessons from New York City and Hong Kong. Landscape and Urban Planning, 97(3), 202-212.
Lund, H., Cervero, R., \& Wilson, R. (2004). Travel characteristics of transit-oriented development in Cali fornia (Transportation grant, statewide planning studies, FTA section 5313b). California: Caltrans. Martens, K. (2004). The bicycle as a feedering mode: Experiences from three European countries. Trans portation Research Part D, 9, 281-294.

MoHUA, M. (2017a). Metro Rail Policy. New Delhi: Government of India.

MoHUA, M. (2017b). Proposed green urban mobility scheme. New Delhi: Government of India.

Morrall, J., \& O'Sullivan, S. (1996). Walking distances to and from light-rail transit stations. Transpor tation Research Record, 1538, 19-26.

MoUD, M. (2015). National transit oriented development (TOD) policy. New Delhi: Government of India.

MoUD, M. (2016). TOD guidance document. New Delhi: Government of India.

O'Connor, D., \& Harrison, O. (2012). Rail catchment analysis in the greater Dublin area. Proceeding of Irish Transport Research Network. Dublin: School of Transport Engineering, Environment and Planning.

O'Sullivan, S., \& Morrall, J. (1995). Walking distance to and from light-rail transit station. Transportation Research Record, 1538(1). doi.org/10.3141/2006-13

Park, S., Deakin, E., \& Jang, K. (2015). Can good walkability expand the size of transit-oriented developments? Transportation Research Record: Journal of the Transportation Research Board, 2519, 157164.

Rastogi, R. (2010). Willingness to shift to walking or bicycling to access suburban rail: Case study of Mumbai, India. Journal of Urban Planning and Development, 136(1). doi.10.1061/(ASCE)07339488(2010)136:1(3)

Rastogi, R. (2011). Promotion of non-motorized modes as a sustainable transportation option: Policy and planning issues. Current Science, (100)9, 1340-1348.

Rastogi, R., \& Krishna Rao, K. (2003). Travel characteristics of commuters accessing transit: A cas study. Journal of Transportation Engineering, 129(6), 684-694.

Renne, J. L. (2009). Transit oriented development—-making it happen. London: Routledge

Rietveld, P. (2000). Non-motorised modes in transport systems: A multimodal chain perspective for the Netherlands. Transportation Research Part D: Transport and Environment, 5, 31-36.

Rodrigue, J. P. (2017). The geography of transport systems. New York: Routledge.

Salvensen, D. (1996). Promoting transit oriented development. Urban Land, 55(7), 31-35.

Shastry, S. (2010). Spatial assessment of transit oriented development in Abmedaba (MS thesis). Enschede, Netherlands: University of Twente.

Still, T. (2002). Transit-oriented development: Reshaping America’s metropolitan landscape. On Common Ground, 44-47.

Sung, H. (2011). Transit-oriented development in a high-density city: Identifying its association with transit ridership in Seoul, Korea. Cities, 28, 70-82.

Taylor, D., \& Mahmassani, H. (1996). Analysis of stated preferences for intermodal bicycle-transit interfaces. Transportation Research Record, 1556, 87-95

Thomas, R., Pojani, D., Lenferink, S., Bertolini, L., Dominic, S., \& van der Krabben, E. (2018). Is transit-oriented development (TOD) an internationally transferable policy concept? Regional Studies, 52, 1201-1213.

Untermann, R. (1984). Accommodating the pedestrian: Adapting towns and neighborhoods for walking and biking. New York: Van Nostrand Reinhold.

UTTIPEC. (2012). Transit oriented development — policy, norms, guidelines. New Delhi: Delhi Development Authority. 
Van Goeverden, C., \& Egeter, B. (1993). Gecombineerd gebruik van fiets en openbaar vervoer: Verwachte effecten opde vervoerwijzekeuze van optimale fietsheschikbaarheid. Delft: Voor-en Natransport. TU Delft, Faculteit der Civiele.

Wilson, S. A. (2013). Ahmedabad: Leapfrogging from medieval to modern mobility. In Megacity mobility culture: How cities move on in a diverse world (pp. 67-87). Munich: Springer.

Zhao, F., Chow, L.-F., Li, M.-T., \& Gan, A. (2003). Forecasting transit walk accessibility: A regression model alternative to the buffer method. TRB 2003 Annual Meeting, Washington, DC.

Zielstra , D., \& Hochmair, H. (2011). Comparative study of pedestrian accessibility to transit stations using free and proprietary network data. Transportation Research Record: Journal of the Transportation Research Board, 2217, 145-152. 